\title{
Charged and total particle formation and growth rates during EUCAARI 2007 campaign in Hyytiälä
}

\author{
H. E. Manninen ${ }^{1}$, T. Nieminen ${ }^{1}$, I. Riipinen ${ }^{1}$, T. Yli-Juuti ${ }^{1}$, S. Gagné ${ }^{1}$, E. Asmi ${ }^{1,2}$, P. P. Aalto ${ }^{1}$, T. Petäjä ${ }^{1}$, \\ V.-M. Kerminen ${ }^{2}$, and M. Kulmala ${ }^{1}$ \\ ${ }^{1}$ Department of Physics, University of Helsinki, P.O. Box 64, 00014 Helsinki, Finland \\ ${ }^{2}$ Finnish Meteorological Institute, Research and Development, P.O. Box 503, 00101 Helsinki, Finland
}

Received: 22 December 2008 - Published in Atmos. Chem. Phys. Discuss.: 25 February 2009

Revised: 25 May 2009 - Accepted: 8 June 2009 - Published: 22 June 2009

\begin{abstract}
Despite the fact that frequent aerosol formation has been observed in various locations in the atmosphere, the overall magnitude of the new particle formation as a particle source is still unclear. In order to understand the particle formation and growth processes, we investigate the magnitudes of the particle formation and growth rates at the size where the real atmospheric nucleation and activation occurs. The relative contribution of neutral and charged particles to the new particle formation rate is also studied. The data include particle and ion number size distributions and total particle concentration measurements at a boreal forest site in Hyytiälä, Finland, during the spring 2007 EUCAARI field campaign. The total and charged particle formation rates differed from each other by approximately an order of magnitude. The median formation rates of $2 \mathrm{~nm}$ total and charged particles were $0.65 \mathrm{~cm}^{-3} \mathrm{~s}^{-1}$ and $0.03 \mathrm{~cm}^{-3} \mathrm{~s}^{-1}$, respectively. The median growth rates of particles in size classes $1.3-3,3-7$ and 7-20 nm were 1.9, 3.6 and $4.2 \mathrm{nmh}^{-1}$, respectively. The calculated ion-ion recombination rates were about the same order of magnitude as the ion-induced formation rates. The results indicate that the ion-induced nucleation involving the ion-ion recombination products, i.e. ion mediated nucleation, contributes approximately $10 \%$ to the boreal forest new particle formation events.
\end{abstract}

\section{Introduction}

Aerosol particles affect atmospheric opacity and cloud properties and thereby the climate by influencing the radiation budget in both regional and global scales (Cabada et al.,

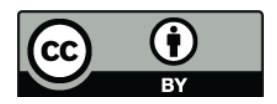

Correspondence to: H. E. Manninen (hanna.manninen@helsinki.fi)
2004; Lohmann and Feichter, 2005). Particles nucleated and grown in the atmosphere may participate in the cloud formation processes by acting as cloud condensation nuclei ( $\mathrm{Li}-$ havainen et al., 2003; Kerminen et al., 2005; Kuwata et al., 2008). Consequently, we are working to decrease uncertainties in assessing the climatic effects of the newly-formed particles and increasing the level of scientific understanding of their role in the on-going climate change (IPCC, 2007).

Formation of atmospheric particles by nucleation of vapors and subsequent growth of the particles by condensation are observed world-wide in various environments (Kulmala et al., 2004a; Kulmala and Kerminen, 2008). The list of locations and altitudes where frequent aerosol formation has been observed is still growing (Wu et al., 2007; Laakso et al., 2008; Venzac et al., 2008). The Amazon rain forest seems to be the only place so far where new particle formation (NPF) and growth has not been observed when measured with proper instrumentation. The overall magnitude of new particle formation as a particle source is uncertain in regional and global scales. Recent model studies suggest that in the atmosphere nucleation may be a globally important source of aerosol particles and cloud condensation nuclei (Spracklen et al., 2006, 2008; Yu et al., 2008). The detailed formation mechanisms and the chemical composition of vapors participating in particle formation processes remain unclear due to lack of direct atmospheric measurements. The particle formation characteristics, such as formation and growth rates, can be used as indicators of the relevant processes and participating compounds in the initial formation.

In order to understand the atmospheric particle formation and growth processes, we need to measure directly the very initial steps of the formation processes. The atmospheric nucleation and cluster activation take place at particle sizes close to $1.5-2 \mathrm{~nm}$ in mobility diameter, i.e. Millikan diameter (Kulmala et al., 2007a). Atmospheric ions and charged particles can be detected down to the sizes smaller than $1 \mathrm{~nm}$ with

Published by Copernicus Publications on behalf of the European Geosciences Union. 
air ion spectrometers (Mirme et al., 2007; Tammet, 2006). However, the concentrations of small ions are usually so low that they cannot solely explain the observed new particle formation events (Laakso et al., 2004). The current commercial instruments detect particles down to the 3-nm size. The lack of atmospheric observations of electrically neutral aerosol particles below this size obligates us to put a significant effort into the development of instruments that measure the uncharged particles smaller than $3 \mathrm{~nm}$ (Kulmala et al., 2007a; Riipinen et al., 2009; Sipilä et al., 2008, 2009).

Several studies (see e.g. O'Dowd et al., 2002; Kulmala et al., 2004b; Hirsikko et al., 2005 and Riipinen et al., 2009) suggest that sulfurous compounds contribute to the initial steps of the NPF and to the subsequent growth, and that organics participate in the later steps of the growth. Smith et al. (2008) reported that, based on the composition measurements of ambient particles and the independent model calculation, organics can play a dominant role in the growth of particles from a size of 10 to $30 \mathrm{~nm}$ as compared to sulfur species. The importance of ion-induced nucleation in the observed new particle formation is under discussion (Kazil et al., 2008). Gagné et al. (2008) reported that, on average, the NPF events in Hyytiälä, Finland, were clearly dominated by neutral particle nucleation and ion-induced nucleation had a minor contribution. In Hyytiälä, the median observed contribution of ion-induced nucleation was around 6.4\%. In Boulder, Colorado, the average contribution of ion-induced nucleation was about $0.5 \%$ in both polarities (Iida et al., 2006). Therefore, both studies showed minor contribution of ioninduced nucleation to the total particle formation. On the other hand, Yu and Turco (2008) reported that their model of ion-mediated nucleation (ion-induced nucleation involving ion-ion recombination products) was able to explain most of the particle formation observed during QUEST IV campaign in Hyytiälä during spring 2005.

In this study we explore formation and growth of fresh atmospheric aerosol particles and ions. The purpose of this paper is to investigate the magnitude of the particle formation and growth rates close to the size where the real atmospheric nucleation and activation occurs, as well as to investigate the relative contribution of neutral and charged particles to the new particle formation. With a suite of recently developed instruments (Tammet, 2006; Kulmala et al., 2007a, b; Mirme et al., 2007) we were able to determine growth rates as a function of particle and ion mobility diameter during the particle nucleation events, as well as particle formation rates at our lowest cut-off size of $2 \mathrm{~nm}$. Furthermore, we demonstrate a methodology for determining experimentally the total particle formation rates, which we were able to probe using a difference between the total and ion-induced formation rates while also taking into account the ion-ion recombination. The sensitivity of the results to the experimental measurement uncertainty is also investigated.

\section{Methods}

In this work we used a data set collected during an intensive field campaign conducted within the European Integrated project on Aerosol Cloud Climate and Air Quality Interactions (EUCAARI, Kulmala et al., 2009). The campaign was carried out between 6 March and 30 June 2007 at the SMEAR II station in Hyytiälä $\left(61^{\circ} 51^{\prime} \mathrm{N}, 24^{\circ} 17^{\prime} \mathrm{E}\right.$, $181 \mathrm{~m}$ a.s.l., see Hari and Kulmala, 2005), Finland. The SMEAR II research facility is a rural site surrounded by Scots pine dominated boreal forest. New particle formation is frequently observed in this environment. Typically 60-120 NPF events are observed annually (Dal Maso et al., 2005) having a maximum in the frequency during spring months.

The measurement set-up includes complementary instruments for detecting negative and positive air ions and neutral aerosol particles (Hirsikko et al., 2005; Kulmala et al., 2007a; Riipinen et al., 2009). The measurements of sub $3 \mathrm{~nm}$ aerosol particles are challenging. Therefore, we used two different methods to determine their concentration and evolution namely NAIS and CPCB to avoid artifacts; also both instruments were calibrated under laboratory conditions. The performance of the instrumentation was carefully monitored daily throughout the campaign. First, in the data analysis all the campaign days were classified and grouped into different nucleation event classes. Second, the particle growth and formation rates were calculated on the NPF event days in order to characterize the processes leading to the nucleation. Third, the contribution of ions to the particle formation and growth in the boreal forest was investigated.

\subsection{Instrumentation}

\subsubsection{Atmospheric ion and neutral cluster instruments}

The Balanced Scanning Mobility Analyzer (BSMA, see e.g. Hirsikko et al., 2005 and Tammet, 2006) is an instrument capable of measuring mobility distributions of small air ions and naturally charged nanoparticles of both negative and positive polarity. The mobility range of the BSMA is 3.16 to $0.032 \mathrm{~cm}^{2} \mathrm{~V}^{-1} \mathrm{~s}^{-1}$, which corresponds to a mobility diameter range of 0.8 to $8.0 \mathrm{~nm}$ (Tammet, 2006). Hereafter, we refer to mobility diameter i.e. Millikan diameter when converting the measured mobility to the particle diameter (Mäkelä et al., 1996). The BSMA consists of two plain aspiration condensers, one for each polarity, and a common electrical amplifier connected to a balanced bridge circuit. The size segregation is obtained by discharging a capacitor through a repelling electrode and monitoring the electrometer current in the balanced bridge circuit. An inlet gate lets either positive or negative ions pass through the aspiration condenser. The BSMA measured the ion size distributions in a 10-min time resolution.

The Air Ion Spectrometer (AIS, Mirme et al., 2007) measures a mobility distribution of both negative and positive 
air ions in the range from 3.16 to $0.0010 \mathrm{~cm}^{2} \mathrm{~V}^{-1} \mathrm{~s}^{-1}$. This corresponds to a diameter range of approximately $0.8 \mathrm{~nm}$ to $47 \mathrm{~nm}$ (Tammet, 1995). The instrument comprises two parallel units with the opposite polarities. In essence, both polarity units consist a pair of unipolar charger and electrostatic filter for background measurements and a cylindrical differential mobility analyzer (DMA) equipped with insulated electrometer rings for measuring charge on aerosol particles. The sampled ions are collected onto the electrometer rings in 21 electrical mobility fractions simultaneously for both polarities.

The Neutral cluster and Air Ion Spectrometer (NAIS) resembles the AIS, but in addition to the ion size distribution, it also measures the mobility distributions of neutral and charged aerosol particles and sub- $3 \mathrm{~nm}$ clusters. Controlled charging together with the electrical filtering enables to measure the neutral aerosol particles and to distinguish them from cluster ions. The polarity units consist of the same elements as in AIS, with an extra pair of unipolar charger and electrostatic filter. The mobility range of the NAIS is 2.4-0.0010 $\mathrm{cm}^{2} \mathrm{~V}^{-1} \mathrm{~s}^{-1}$ (Kulmala et al., 2007a) which corresponds to a mobility diameter range from $0.9-47 \mathrm{~nm}$. The charger ion mobility varies from 0.6 to $1.6 \mathrm{~cm}^{2} \mathrm{~V}^{-1} \mathrm{~s}^{-1} \mathrm{de}-$ pending on polarity and defines the lowest estimation for the detection limit of approximately $2 \mathrm{~nm}$ (Asmi et al., 2008). Particles below this limit cannot be reliably distinguished from the charger ions. The time resolution for the NAIS and the AIS data was $5 \mathrm{~min}$.

\subsubsection{Aerosol particle instruments}

The total concentration of aerosol particles was measured by the Condensation Particle Counter Battery (CPCB, Kulmala et al., 2007b) with a time resolution of $10 \mathrm{~s}$. In the analysis, the CPC data was averaged over 5 to 10 -min time intervals to make it comparable with the other available aerosol data. The CPCB consists of four Condensation Particle Counters (CPCs, see e.g. McMurry, 2000): one butanol- and waterCPC pair with cut-off diameter $3 \mathrm{~nm}$ calibrated for insoluble silver particles (TSI-3776, TSI-3786 [UWCPC]) and the other pair with cut-off diameter $6 \mathrm{~nm}$ for silver particles (TSI3772, TSI-3785). The idea behind CPCB is to study the water solubility of nanoparticles, having the same calibrated cut-off diameters for water- and butanol-CPCs in the case of insoluble particles. According to laboratory calibrations, the CPCB is able to detect aerosol particles as small as $2 \mathrm{~nm}$ in diameter (Kulmala et al., 2007b) when the solubility of the nucleation mode particles to the condensing vapor of the CPC results in a decrease of the heterogeneous activation diameter inside the CPC. Water-CPCs detect hygroscopic particles down to lower particle sizes compared to butanol-CPCs due to increased activation probability in water vapor. Respectively, the activation probability of lipophilic particles is higher in butanol vapor than in water. During the NPF events in Hyytiälä, the smallest particles activate for growth at smaller sizes in water than in butanol vapor (Riipinen et al., 2009). Before and during measuring in the field, the cut-off size of each CPC was adjusted by varying the temperature difference between the saturator and the growth tube with laboratory generated insoluble silver particles (Petäjä et al., 2006).

The Differential Mobility Particle Sizer (DMPS) system (Aalto et al., 2001) measures continuously the atmospheric aerosol particle number size distribution between 3-1000 nm in diameter at the SMEAR II station. The system consists of two parallel DMPS devices: the first one classifies particles between 3 and $40 \mathrm{~nm}$ (with a TSI-3025) and the second one between 15 and $1000 \mathrm{~nm}$ (with a TSI-3010). Both devices use a Hauke-type DMA in a closed loop sheath flow arrangement (Jokinen and Mäkelä, 1996) and share a radioactive neutralizer (Ni-63). The DMPS has a time resolution of 10 min.

\subsection{Data analysis}

\subsubsection{Classifying new particle formation events}

The particle formation events observed in Hyytiälä typically take place in a regional scale (Mäkelä et al., 2000; Kulmala et al., 2001). Therefore, the formation and subsequent growth can be seen in a time series of size distributions measured at SMEAR II station. The NPF classification is based on the distinct shape of the formation and growth observed on the contour plots of the time series of the number size distribution. The classification was performed visually from the DMPS data using the daily contour plots of the size distribution evolution. Following work of Dal Maso et al. (2005), the data was categorized into three main classes, namely event, non-event and undefined days. The event days were classified further into subclasses Ia, Ib and II according to the shape of the growing nucleation mode and possibility to use the size distribution data in further study of the event day, for instance, in growth rate analysis. Class Ia events had a clear continuous shape as the formation of particles and subsequent evolution towards large sizes continued for several hours. In class Ib events the clear and continuous growth did not start at cluster sizes or the growth was suppressed. Class II events had unclear shape of growing mode indicating inhomogeneity of the studied air mass.

The time series of the ion number size distributions were used in another classification scheme using a method presented by Hirsikko et al. (2007). The results were slightly different compared to the classification based on DMPS data. Some of the NPF events were detected only by the ion spectrometers below the lower detection limit of the DMPS system. Such events were neglected in the subsequent steps in this study, as they could not be analyzed for the event characteristics. 


\subsubsection{Estimating charged and total particle growth rates}

During the first steps of NPF, the number concentration of the smallest particles increases, creating a concentration peak in the number size distribution. The subsequent particle growth shifts the concentration peak towards larger sizes. The rate at which the newly formed aerosol population grows can be determined from the measured size distributions. The Hirsikko et al. (2005) method was used to estimate the ion and particle growth rates $(G R)$. A normal distribution function was fitted into the time series of the particle concentrations in a certain size fraction. After determining the moment corresponding to the maximum concentration in each of the size fraction, the growth rates were obtained by a first order linear leastsquare fit through the data points in the selected size classes.

The total and charged particle growth rates were estimated for three size classes: $1.3-3 \mathrm{~nm}, 3-7 \mathrm{~nm}$ and 7-20 nm. The $G R$ of the charged particles was estimated in all three classes from the AIS data and in the two first classes from the BSMA measurements. For the ion data, both polarities were analyzed separately. The total $G R$ was estimated from the DMPS data for 3-7 $\mathrm{nm}$ and $7-20 \mathrm{~nm}$ particles. In principle the NAIS can also be utilized for growth rate estimations. The preliminary analysis using NAIS data gives corresponding values for growth rates. It should be noted that the growth rate is calculated for the particle population, not for individual particles. On some of the NPF days the growth rate calculation was not successful due to e.g. changes in air masses or clearly local particle emissions. These days were excluded from the growth rate analysis.

The growth rates estimated in this study are directly calculated from the observed number size distributions i.e. apparent growth rates (e.g. McMurry et al., 2005; Stolzenburg et al., 2005). The apparent growth rate includes condensational growth due to various vapors as well as growth due to both internal and external coagulation. Condensation and self-coagulation represent real growth of the particles, whereas external coagulation shifts the nucleation mode towards larger sizes by favoring the smallest particles in the mode and apparently growing the geometric mean diameter of the mode. This process is strongly dependent on the coagulation sink provided by the pre-existing population. However, coagulation is very likely to be insignificant under the conditions encountered during the study period (Kerminen et al., 2004).

\subsubsection{Calculating total and charged particle formation rates at $2 \mathrm{~nm}$}

The particle formation rate at $2 \mathrm{~nm}\left(J_{2}\right)$, i.e. flux of particles into $2-3 \mathrm{~nm}$ size range, can be calculated from the particle concentrations detected in the size range of 2-3 nm, taking into account the coagulation scavenging to the larger preexisting particles, as well as the growth out of the $3 \mathrm{~nm}$ size range (Kulmala et al., 2007a). The following formula describes the total particle formation rate

$J_{2}=\frac{\mathrm{d} N_{2-3}}{\mathrm{~d} t}+\operatorname{Coag} S_{2} \cdot N_{2-3}+\frac{f}{1 \mathrm{~nm}} G R_{3} N_{2-3}$.

Here the time derivative of $N_{2-3}$ is directly obtained from the NAIS or CPCB measurements. The number concentration of 2-3 nm particles were obtained from size distributions measured by the NAIS. In the case of the CPCB data, the number concentration of these particles were calculated as a concentration difference between the CPCB and DMPS readings, when the UWCPC cut-off size during NPF event is typically close to $2 \mathrm{~nm}$ (Riipinen et al., 2009), whereas the DMPS detection limit is $3 \mathrm{~nm}$. Our aim was to calculate the momentary values of $J_{2}$ during the NPF events. In order to determine $d N_{2-3} / d t$, we selected a time period between the first appearance and the time of a maximum concentration from the time series of $2-3 \mathrm{~nm}$ particle number concentration. In other words, we chose the periods when the particle number concentration showed a monotonic increase during the events.

The term $\operatorname{CoagS}_{2}$ denotes an average coagulation sink for the $2 \mathrm{~nm}$ particles (Kulmala et al., 2001). The sink was calculated for every $10 \mathrm{~min}$ from the background particle size distribution measured by the DMPS system, with hygroscopicity effects estimated as in Laakso et al. (2004). The values of the $\operatorname{CoagS}_{2}$ and the $N_{2-3}$ were averaged over the same selected period that was used to calculate rate of change, $d N_{2-3} / d t$. The third term in the Eq. (1) represents the loss rate of particles due to the condensational growth out of the size range $2-3 \mathrm{~nm}$. The growth rate, $G R_{3}$, in the size range $1.3-3 \mathrm{~nm}$ was calculated from the BSMA data. The factor $f$ presents a fraction of $2-3 \mathrm{~nm}$ particles that were activated for the growth, assumed to be unity in this study. As a result, the values for the $J_{2}$ can be considered as upper limits for the particle formation rates. Note that the values of the two last terms in Eq. (1) would have been smaller if the mean value were taken over the observed particle formation period (the time between the first and last appearance of 2-3 nm particles).

In the case of charged particles, the ion-ion recombination and charging of 2-3 nm neutral particles need to be taken into account. The formation rate of $2-3 \mathrm{~nm}$ charged particles can be expressed as

$$
\begin{aligned}
J_{2}^{ \pm} & =\frac{\mathrm{d} N_{2-3}^{ \pm}}{\mathrm{d} t}+\operatorname{Coag} S_{2} \cdot N_{2-3}^{ \pm} \\
& +\frac{f}{1 \mathrm{~nm}} G R_{3} N_{2-3}^{ \pm}+\alpha \cdot N_{2-3}^{ \pm} N_{<3}^{\mp}-\beta \cdot N_{2-3} N_{<2}^{ \pm},
\end{aligned}
$$

where the superscript \pm refers to positively and negatively charged particles, respectively, $N_{2-3}^{ \pm}$is the $2-3 \mathrm{~nm}$ ion concentration, and $N_{<2}^{ \pm}$is the ion concentration below $2 \mathrm{~nm}$. The ion-ion recombination coefficient, $\alpha$, and ion-neutral attachment coefficient, $\beta$, were assumed to be equal to $1.6 \cdot 10^{-6} \mathrm{~cm}^{3} \mathrm{~s}^{-1}$ and $0.01 \cdot 10^{-6} \mathrm{~cm}^{3} \mathrm{~s}^{-1}$, respectively (see 


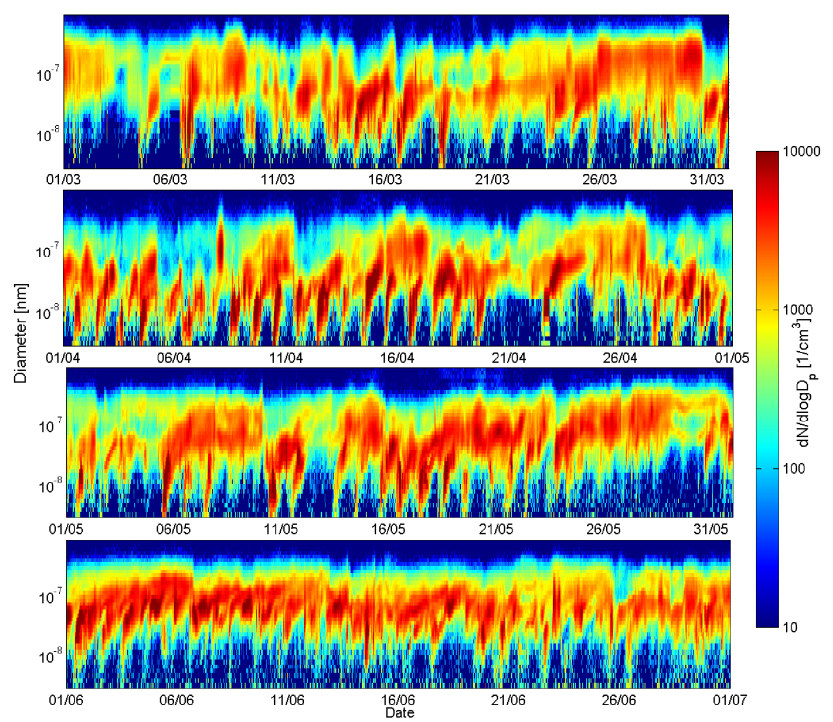

Fig. 1. Particle size distributions measured by a DMPS system during the EUCAARI 2007 spring (6 March-31 March 2007) campaign in Hyytiälä.

e.g. Tammet and Kulmala, 2005). The ion concentrations were obtained from the AIS and BSMA number size distributions.

\subsubsection{Calculating ion-ion recombination rates at $2 \mathrm{~nm}$}

Atmospheric ions may affect the observed particle formation by producing neutral atmospheric clusters. The ion-ion recombination products can be activated to growth by condensation of vapors. This process contributes to the total formation rate. Kulmala et al. (2007a) wrote a balance equation describing the time evolution of the neutral cluster concentration due to the ion-ion recombination alone. The equation included a production term accounting for collisions between ions of opposite polarity leading to the formation of stable neutral clusters, charging of 2-3 nm neutral particles and a loss term accounting for coagulation into the larger pre-existing particles.

The concentration of neutral clusters due to the ion-ion recombination, $N_{n, \text { rec }}$, can be written in a steady state as follows

$N_{n, \text { rec }}=\frac{\delta \times \alpha \times N_{i}^{+} \times N_{i}^{-}}{\operatorname{CoagS}\left(N_{n, r e c}\right)}$.

The factor $\delta$ is a probability that a collision between two ions of opposite polarity leads to the formation of a stable neutral cluster. Here we assumed that $\delta=1$. The value of $\operatorname{Coag} S$ was determined for $2 \mathrm{~nm}$ particles from the DMPS particle number size distribution. In the calculations of the recombination rates, the mean values of the coagulation sink and ion concentration over the observed formation period were used.

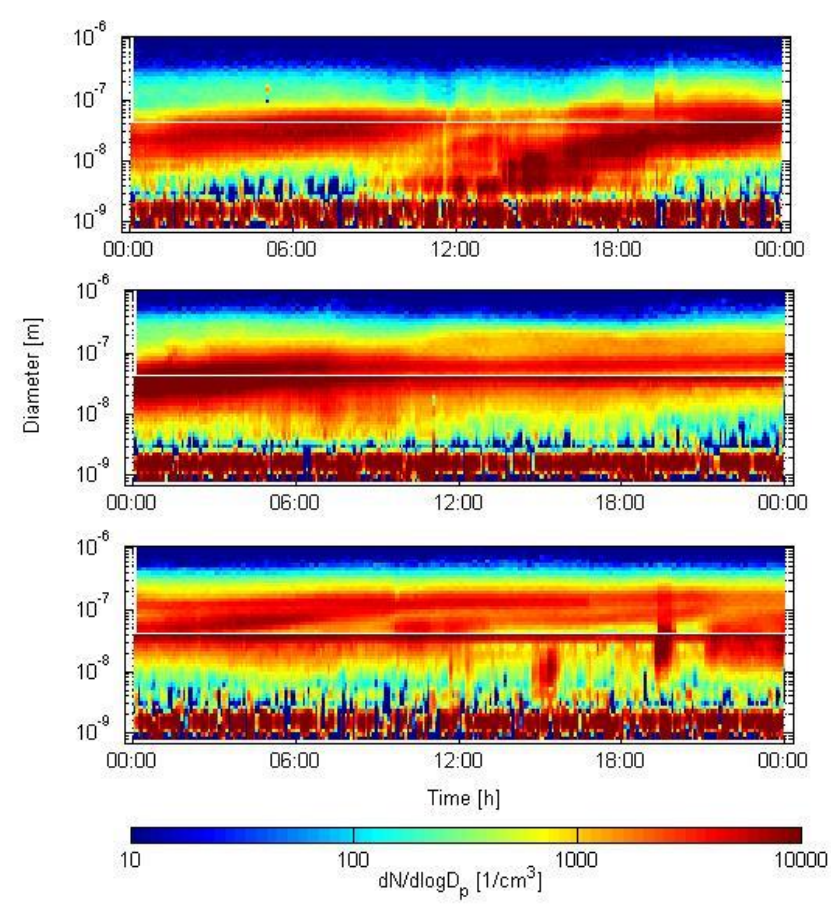

Fig. 2. New particle formation event on 31 March 2007 (top), nonevent on 23 April 2007 (middle) and undefined day on 13 June 2007 (bottom) at the SMEAR II station, Hyytiälä. Particle size distributions were measured with the NAIS in size range $0.8-45 \mathrm{~nm}$ and with the DMPS in size range $45-1000 \mathrm{~nm}$.

The size range of $N_{i}^{+}$and $N_{i}^{-}$were selected in such a way that the diameter of the resulting neutral particle (ion-ion recombination product) was in size range $2-3 \mathrm{~nm}$.

\section{Results and discussion}

\subsection{Event statistics}

The campaign dataset comprised a total of 117 days. All of the analyzed days were classified into event, non-event and undefined days. NPF events were observed on $46 \%$ (54) of the days, while $18 \%$ (21) of the days were categorized as a non-event. The rest of the days $36 \%$ (42) were classified as undefined. In other words, roughly every second day was found to have a particle formation burst. Figure 1 shows a time series of the particle size distributions measured with the DMPS during the EUCAARI field campaign. The distinct shape of NPF and growth events was observed frequently on the contour plot series of number size distribution representing the spring 2007.

Examples of the particle number size distribution for the three main classification groups are presented in Fig. 2. Note that the particle number size distributions in Fig. 2 are a combination of the data measured with the NAIS (particles 
Table 1. Event statistics. The total number of event days, nonevent days and undefined days during each month of the intensive EUCAARI 2007 campaign at Hyytiälä. The nucleation event days were classified further into tree subclasses according to their quality. All of the 117 campaign days were classified.

\begin{tabular}{llllll}
\hline & March & April & May & June & Total \\
\hline Events & 10 & 22 & 15 & 7 & 54 \\
class Ia & 2 & 3 & 2 & 0 & 7 \\
class Ib & 3 & 14 & 6 & 2 & 25 \\
class II & 5 & 5 & 7 & 5 & 22 \\
Undefined & 10 & 4 & 9 & 19 & 42 \\
Non-events & 6 & 4 & 7 & 4 & 21 \\
\hline
\end{tabular}
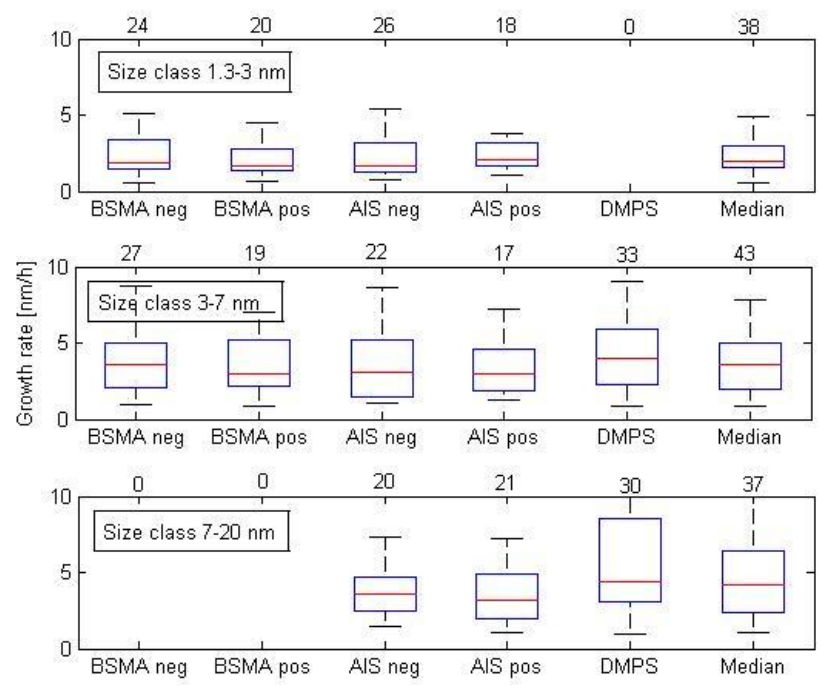

Fig. 3. Growth rates during NPF events in spring 2007 in different size ranges and methods. The red lines show the medians, the boxes indicate the 25- and 75-percentiles, and the error bars the 5- and 95percentiles. The numbers above the subplots refer to the number of NPF event days included in the analysis.

smaller than $45 \mathrm{~nm}$ ) and with the DMPS (particles larger than $45 \mathrm{~nm}$ ). Most of the events (41\%) were observed on April, while the number of undefined days was found to have a minimum then. The intensive field campaign was timed for the spring due to earlier observation by Dal Maso et al. (2005), according to which the NPF events occur more frequently during spring than during other times of the year. The event characteristics, presented later in this paper and listed in Appendix A (Table A1), were successfully calculated for the class Ia and $\mathrm{Ib}$ events. A detailed classification of the NPF events into the subclasses during each month of the campaign is shown in Table 1.

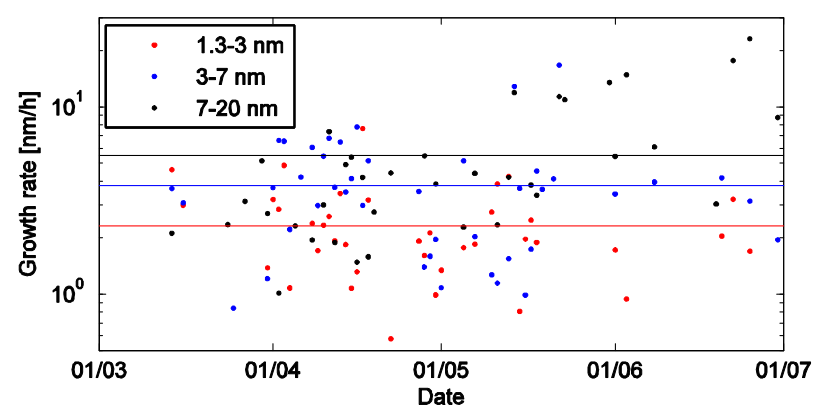

Fig. 4. Time series of the calculated growth rates. The median growth rates (solid lines) of 1.3-3 nm (red dots), 3-7 nm (blue dots) and 7-20 nm (black dots) particles according to size distributions measured with AIS, BSMA and DMPS during the EUCAARI field campaign.

\subsection{Particle growth and formation rates}

The growth rates of freshly-formed particles were estimated for the whole measurement period with data from three different instruments and three different size classes (Fig. 3). The data from the different instruments yielded consistent results for each size class. The median growth rates of particles in size classes $1.3-3,3-7$ and 7-20 nm were equal to 1.9, 3.6 and $4.2 \mathrm{~nm} \mathrm{~h}^{-1}$, respectively. The upper panel in Fig. 3 contains the growth rates of $1.3-3 \mathrm{~nm}$ charged particles determined from both polarities of the BSMA and AIS data. The middle panel depicts the growth rates of 3-7 nm charged particles from the both polarities of the BSMA and AIS, as well as the growth rates for the particles from the DMPS. The bottom panel contains growth rates of 7-20 nm charged and uncharged particles from the AIS and DMPS data. Due to limitations in the measurement range, GR could not be calculated for all three size classes in case of the BSMA and DMPS.

Figure 4 shows a time series of estimated median growth rates of $1.3-3,3-7$ and $7-20 \mathrm{~nm}$ particles, as obtained with the different methods. The median GR of $1.3-3 \mathrm{~nm}$ particles was $2.3 \mathrm{~nm} \mathrm{~h}^{-1}$, varying from $0.6 \mathrm{~nm} \mathrm{~h}^{-1}$ to $7.7 \mathrm{~nm} \mathrm{~h}^{-1}$. The median GR of 3-7 and 7-20 nm particles were 3.8 and $5.5 \mathrm{~nm} \mathrm{~h}^{-1}$, respectively, and the corresponding ranges were $0.7-16.7$ and $0.8-23 \mathrm{nmh}^{-1}$. The relative difference between the AIS and BSMA growth rates varied from day to day. On average, the BSMA gave approximately $10 \%$ higher growth rate than the AIS.

The median growth rate from all the data showed an increase with an increasing particle size. The growth rate by condensation is dependent on the particle size and on the saturation vapor pressure of the condensing compound. Note that the condensing vapors that participate in the first steps of the particle growth may be different than the vapors contributing to the later steps of the growth. A temporal variation 


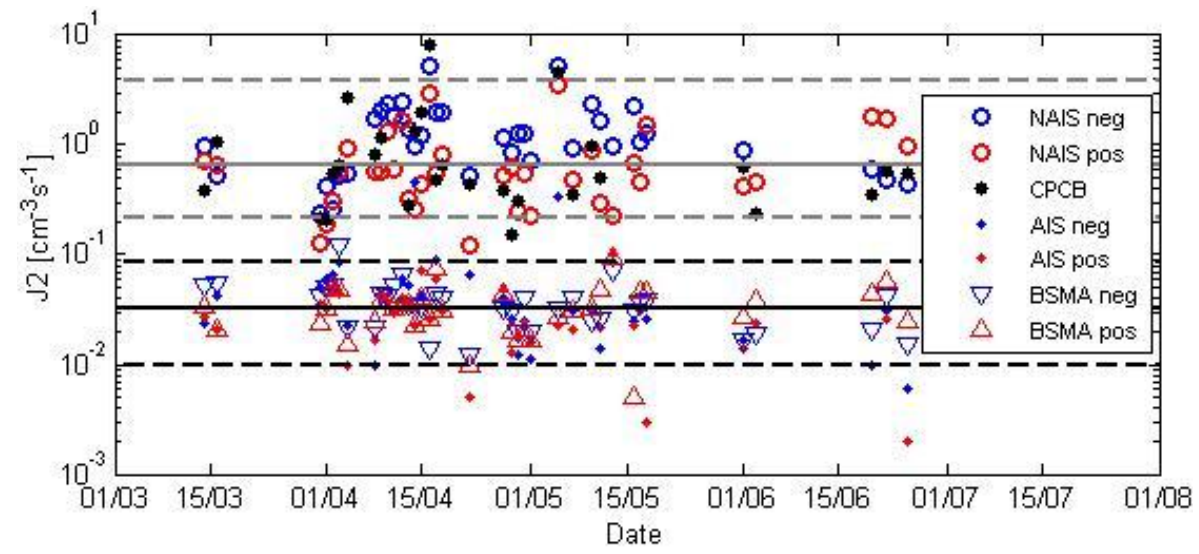

Fig. 5. The calculated $2 \mathrm{~nm}$ total particle formation rates from both polarities of the NAIS and the CPCB data and ion-induced nucleation rate obtained from both negative and positive polarities of the AIS and BSMA during NPF events. The solid lines refer to the median values of total (gray) and charged (black) particles. The dash lines refer to the corresponding 5 and 95 percentiles.

in a seasonal scale showed a clear increase in the growth rates of 7-20 nm particles towards the summer (Fig. 4, black circles). A plausible explanation for this is the temperature dependent emissions of various organic compounds (Tarvainen et al., 2005), which, after oxidation in the atmosphere, could be mainly responsible for the growth of 7-20 nm particles. The higher $G R$ s in the summer are consistent with the results based on continuous ion number size distribution measurements in Hyytiälä as presented in Hirsikko et al. (2005). Ehn et al. (2007) and Riipinen et al. (2009) measured the hygroscopic properties of nucleation mode particles in Hyytiälä and observed that the relative role of less hygroscopic organic compounds compared to the more hygroscopic ones, such as sulfurous substances, increases with increasing particle size. On average, negative particles had higher growth rates than positive ones (Fig. 3), which suggests that condensing vapors favor negative ions as a seed.

The calculated charged and total particle formation rates at $2 \mathrm{~nm}$ with different measurement methods are presented in Fig. 5. The total and charged particle formation rates differed from each other by more than an order of magnitude. The median total formation rate of $2 \mathrm{~nm}$ particles was $0.65 \mathrm{~cm}^{-3} \mathrm{~s}^{-1}$ varying from 0.22 to $3.9 \mathrm{~cm}^{-3} \mathrm{~s}^{-1}$. On the other hand, the median formation rate of $2 \mathrm{~nm}$ charged particles was $0.03 \mathrm{~cm}^{-3} \mathrm{~s}^{-1}$ varying from 0.01 to $0.09 \mathrm{~cm}^{-3} \mathrm{~s}^{-1}$. The values of $J_{2}$ and $J_{2}^{ \pm}$stayed fairly constant during the whole spring with no clear trend in the formation rates were being observed. The total aerosol particle concentrations used in the calculations were measured with both polarities of the NAIS and with the CPCB, whereas the charged particle concentrations were obtained from both polarities of the AIS and the BSMA.

With regard to the accuracy of the method, the total particle formation rates $\left(J_{2}\right)$ were calculated from the data of three independent instruments (Fig. 6 upper panel). The to- tal concentrations of $2-3 \mathrm{~nm}$ charged and uncharged particles were observed with both polarities of the NAIS and with two ultra-fine CPCs in the CPCB, as mentioned earlier. During the NPF events in Hyytiälä, the ambient cut-off size of the CPCB was typically close to $2 \mathrm{~nm}$ (see Kulmala et al., 2007b; Riipinen et al., 2009). The total particle concentration between $2 \mathrm{~nm}$ and $3 \mathrm{~nm}$ can be determined by comparing the total number concentrations measured by the DMPS system and the CPCs. The charge particle formation rates i.e. ion-induced formation rates were determined with the AIS and BSMA ion data (Fig. 6 lower panel). Again, all the different measurement methods gave consistent results. The greater deviation in total formation rates, as compared with ion-induced formation rates, can be explained by the uncertainties resulting from the measurements below the 3-nm detection limit for neutral particles (Sipilä et al, 2008). The cut-off sizes of the CPCB and NAIS may slightly fluctuate during the campaign under different conditions. Nevertheless, the CPCB and NAIS are totally independent methods yielding consistent results.

\subsection{Particle formation mechanism}

In this study the charged particle formation rates at $2 \mathrm{~nm}$ were typically an order of magnitude lower than the corresponding total particle formation rates. Figure 7 represents diurnal behavior of the charged and uncharged $J_{2}$ during a new particle formation event. Clearly, the ion-induced formation rate was not large enough to explain the observed total formation rates of new particles during this day. Since most of the measurement days showed features similar to Fig. 7, we may conclude that the ion-induced nucleation is only a minor nucleation process in the boreal forest environment. The different activation properties of charged and neutral particles are visible in Fig. 7: the ion-induced formation rates from 

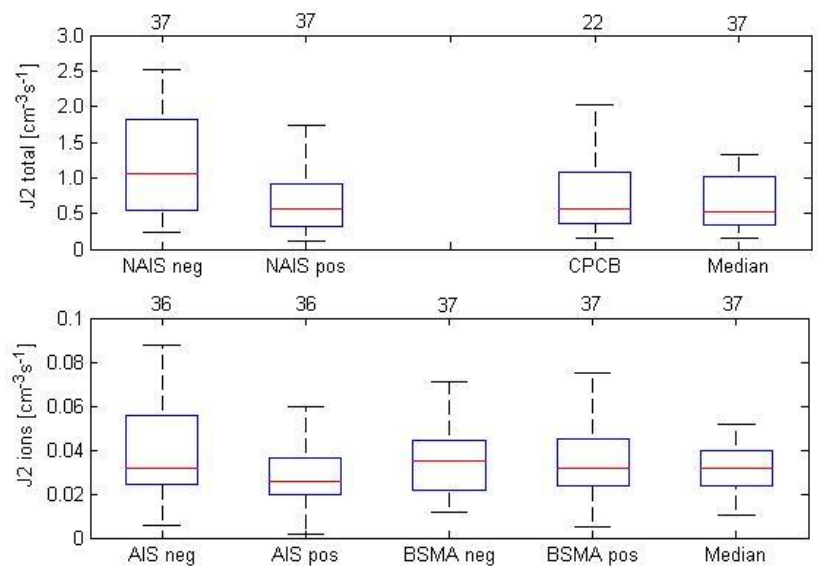

Fig. 6. The formation rates at $2 \mathrm{~nm}$ for total (top) and charged (bottom) particles during NPF events in spring 2007 acquired with different methods. The red lines show the medians, the boxes indicate the 25- and 75-percentiles, and the error bars the 5- and 95percentiles. The numbers above the subplots refer to the number of NPF event days included in the analysis.

the BSMA data increased somewhat before a corresponding increase in the total $J_{2}$ is seen. Based on the laboratory experiments, Winkler et al. (2008) have shown that a lower supersaturation is needed to activate charged clusters than the neutral ones.

The ions and their recombination products (ion-mediated nucleation) explain about $10 \%$ of the particle formation (Fig. 8, lower panel black circles). A maximum contribution of the recombination reaches values close to $70 \%$ on two of the days out of the 37 NPF event days. Even on these two days the high relative contribution is reached due to concurrent low values in the total formation rates and high values in the ion-induced formation rates. The median values of the ion-ion recombination rates were about $0.05 \mathrm{~cm}^{-3} \mathrm{~s}^{-1}$, varying from 0.03 to $0.1 \mathrm{~cm}^{-3} \mathrm{~s}^{-1}$ (Fig. 8, upper panel). The result that in the boreal forest the contribution of ions to particle formation is approximately $10 \%$ is consistent with the particle charging state measurements by Gagné et al. (2008) performed at the same site. However, our result is in disagreement with model studies of ion-mediated nucleation by Yu and Turco (2008). The dominance of the neutral over the ion-induced nucleation is in agreement with the observations by Eisele et al. (2006) at an urban site in Atlanta Georgia.

\subsection{On the sensitivity of the results}

The sensitivity of the total particle formation rate to uncertainties in the growth rate, coagulation sink and particle concentration was investigated. The uncertainty range of the calculated total formation rates at $2 \mathrm{~nm}$ was obtained by assuming that the real growth rate of 2 to $3 \mathrm{~nm}$ particles might be a factor of 2 lower or higher than the growth rate estimated

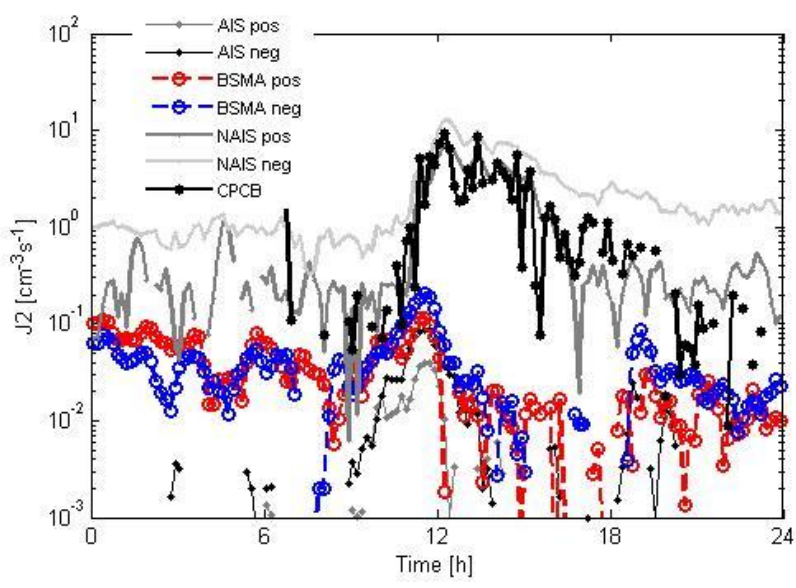

Fig. 7. Comparison of charged and uncharged formation rates during NPF on 5 May 2007 in Hyytiälä. Charged formation rates are measured with AIS (negative polarity, black line with dots and positive polarity, grey line with dots) and with BSMA (negative, blue circles and positive polarity, red circles). Uncharged formation rates are measured with NAIS (negative polarity, dark grey and positive polarity, light grey) and with CPCB (black stars).

from the ion number size distribution measurements due to observational uncertainty. The estimated coagulation sink for the $2 \mathrm{~nm}$ particles and the measured concentration of 2-3 nm particles were assumed to have relative uncertainty of $10 \%$, in case of coagulation sink, mainly due to experimental error related to sink determination and DMPS measurements. As a result, the values for the real $J_{2}$ can be approximately a factor of 1.9 lower or higher than the calculated total formation rates. A closer analysis revealed that the growth out off the size range dominates the $J_{2}$ calculations. The calculated total formation rates consist of three terms (see Eq. 1): a time evolution of 2-3 nm particle concentrations, coagulation losses and growth out of the size range. The median contribution of each these three terms out of the total $J_{2}$ (for NAIS data during all the observed NPF events) were 20\%, $13 \%$ and $67 \%$, respectively.

In case of the ion-induced formation rates, the growth losses over the limit of $3 \mathrm{~nm}$ had the highest impact on the formation rates. Two additional terms - the ion-ion recombination and the charging of the $2-3 \mathrm{~nm}$ neutral particles - had only small impacts. The value of the real charged particle $J_{2}$ can be approximately factor of 1.7 lower or higher than calculated total formation rate. The median percentage of five terms in Eq. (2) out of the ion formation rate were $14 \%, 10 \%$, $52 \%, 17 \%$ and $6 \%$, respectively. These median values were calculated using BSMA data for the 37 NPF event days.

The median value for daily fractions of ion mediated nucleation is $10 \%$ during spring 2007 in Hyytiälä. As uncertainty estimation for contribution of ion mediated nucleation to NPF, we took into account the uncertainty range of 1.7 for ion-induced formation rates and 1.9 for total formation 


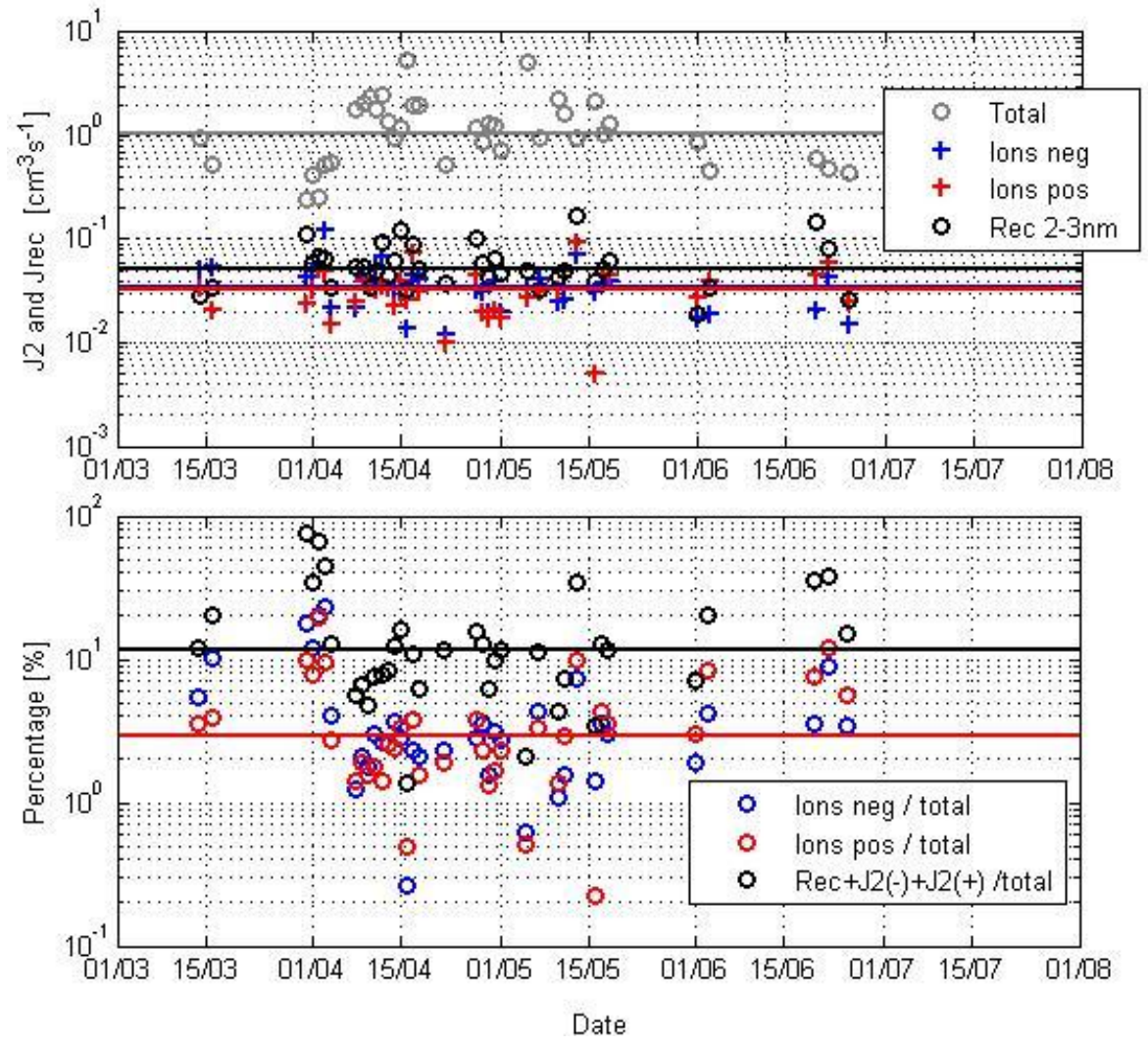

Fig. 8. Upper panel: The total (NAIS neg) and charged (both polarities of BSMA) particle formation rates at $2 \mathrm{~nm}$ and the recombination rate forming neutral clusters at 2-3 $\mathrm{nm}$ during the particle formation event days at spring 2007. Lower panel: The percentage of charged particle formation rate and the sum of recombination and charged formation rates out of the total particle formation rate. The solid lines refer to the median values.

rates. Incorporating the estimated uncertainty ranges into the total and charged particle formation rates, we estimate that, as a median, the ions and their recombination products can explain about $9-15 \%$ of the particle formation. Furthermore, the recombination rate used in the calculations was the maximum, which results in an overestimation of the ioncontribution. In addition, there are several days when ion contribution is dominating ( 2 day during this period).

\section{Conclusions}

We measured particle and ion number size distribution at a boreal forest site in Hyytiälä, Finland. By using recentlydeveloped particle and ion instrumentation (Tammet, 2006; Kulmala et al., 2007a, b; Mirme et al., 2007), we were able measure close to sizes where the very first steps of nucleation and activation processes occur. During the 54 observed nucleation event days, the median growth rates of particles in size classes $1.3-3,3-7$ and $7-20 \mathrm{~nm}$ were equal to 1.9 , 3.6 and $4.2 \mathrm{~nm} \mathrm{~h}^{-1}$, respectively. The size-dependent growth rates obtained from the different instruments gave consistent results with each other. Later in the spring especially $7-20 \mathrm{~nm}$ particles grew faster presumably due to higher concentrations of condensable organic vapors. The increase of growth rate with particle size suggests that the condensing vapors that participate in the first steps of the particle growth may be different than the vapors contributing to the later steps of the growth. We suggest that this could be related to differences in the production rates of condensable vapors as a function of time. The particles formed in a given NPF event typically reach 20-nm size several hours after their initial formation. By this time, the concentration of condensable vapors and their relative ratios has probably changed from the initial conditions due to e.g. differences in the oxidation pathways leading to the condensable products.

Based on our observations, the total and charged particle formation rates at $2 \mathrm{~nm}$, representing the flux of neutral and charged particles into $2-3 \mathrm{~nm}$ size range, differ from each other by approximately an order of magnitude. The median formation rates for $2 \mathrm{~nm}$ total and charged particles were 0.65 and $0.03 \mathrm{~cm}^{-3} \mathrm{~s}^{-1}$, respectively. The estimated relative 
Appendix A

Table A1. New particle formation event dates, classes and characteristics - growth rate of 1.3-3, 3-7 and 7-20 nm particles and ions $\left(\mathrm{GR}_{1.3-3}, \mathrm{GR}_{3-7}\right.$ and $\left.\mathrm{GR}_{7-20}\right)$ and total $\left(J_{2}\right)$ and ion-induced formation rates $\left(J_{2}^{ \pm}\right)$at $2 \mathrm{~nm}$ - in Hyytiälä 6 March-30 June 2007.

\begin{tabular}{|c|c|c|c|c|c|c|c|}
\hline Date & $\begin{array}{l}\text { Event } \\
\text { class }\end{array}$ & $\begin{array}{l}\mathrm{GR}_{1.3-3} \\
{\left[\mathrm{~nm} \mathrm{~h}^{-1}\right]}\end{array}$ & $\begin{array}{l}\mathrm{GR}_{3-7} \\
{\left[\mathrm{~nm} \mathrm{~h}^{-1}\right]}\end{array}$ & $\begin{array}{l}\mathrm{GR}_{7-20} \\
{\left[\mathrm{~nm} \mathrm{~h}^{-1}\right]}\end{array}$ & $\begin{array}{l}\mathrm{J}_{2} \text { total } \\
{\left[\mathrm{cm}^{-3} \mathrm{~s}^{-1}\right]}\end{array}$ & $\begin{array}{l}\mathrm{J}_{2}^{-} \mathrm{neg} \\
{\left[\mathrm{cm}^{-3} \mathrm{~s}^{-1}\right]}\end{array}$ & $\begin{array}{l}\mathrm{J}_{2}^{+} \text {pos } \\
{\left[\mathrm{cm}^{-3} \mathrm{~s}^{-1}\right]}\end{array}$ \\
\hline 14 March 2007 & Ia & 4.62 & 3.65 & 2.11 & 0.96 & 0.05 & 0.03 \\
\hline 15 March 2007 & II & - & - & - & - & - & - \\
\hline 16 March 2007 & $\mathrm{Ib}$ & 2.98 & 3.07 & - & 0.53 & 0.05 & 0.02 \\
\hline 18 March 2007 & II & - & - & - & - & - & - \\
\hline 23 March 2007 & II & - & - & - & - & - & - \\
\hline 24 March 2007 & $\mathrm{Ib}$ & - & - & 2.35 & - & - & - \\
\hline 25 March 2007 & II & - & 0.84 & - & - & - & - \\
\hline 27 March 2007 & II & - & - & 3.12 & - & - & - \\
\hline 30 March 2007 & $\mathrm{Ib}$ & - & - & 5.16 & - & - & - \\
\hline 31 March 2007 & Ia & 1.38 & 1.21 & 2.70 & 0.24 & 0.04 & 0.02 \\
\hline 1 April 2007 & $\mathrm{Ib}$ & 3.19 & 3.69 & - & 0.42 & 0.05 & 0.03 \\
\hline 2 April 2007 & Ia & 2.83 & 6.62 & 1.01 & 0.26 & 0.05 & 0.05 \\
\hline 3 April 2007 & II & 4.87 & 6.54 & - & 0.52 & 0.12 & 0.05 \\
\hline 4 April 2007 & $\mathrm{Ib}$ & 1.08 & 2.22 & - & 0.55 & 0.02 & 0.02 \\
\hline 5 April 2007 & II & - & - & 2.31 & - & - & - \\
\hline 6 April 2007 & II & - & 4.21 & - & - & - & - \\
\hline 8 April 2007 & $\mathrm{Ib}$ & 2.39 & 6.07 & 1.94 & 1.77 & 0.02 & 0.03 \\
\hline 9 April 2007 & $\mathrm{Ib}$ & 1.70 & 2.96 & - & 2.07 & 0.04 & 0.04 \\
\hline 10 April 2007 & $\mathrm{Ib}$ & 2.34 & 5.45 & 2.99 & 2.36 & 0.04 & 0.04 \\
\hline 11 April 2007 & $\mathrm{Ib}$ & 2.60 & 6.79 & 7.36 & 1.78 & 0.05 & 0.03 \\
\hline 12 April 2007 & Ia & 1.92 & 3.71 & 1.88 & 2.51 & 0.07 & 0.04 \\
\hline 13 April 2007 & $\mathrm{Ib}$ & 3.44 & 6.49 & - & 1.37 & 0.04 & 0.04 \\
\hline 14 April 2007 & $\mathrm{Ib}$ & 1.84 & 3.50 & 4.91 & 0.97 & 0.04 & 0.02 \\
\hline 15 April 2007 & Ia & 1.08 & 4.13 & 5.38 & 1.22 & 0.03 & 0.04 \\
\hline 16 April 2007 & $\mathrm{Ib}$ & 1.31 & 7.79 & 1.48 & 5.32 & 0.01 & 0.03 \\
\hline 17 April 2007 & $\mathrm{Ib}$ & 7.66 & 2.97 & 4.20 & 1.95 & 0.05 & 0.08 \\
\hline 18 April 2007 & $\mathrm{Ib}$ & 3.17 & 5.16 & 1.58 & 1.98 & 0.04 & 0.03 \\
\hline 19 April 2007 & $\mathrm{Ib}$ & - & - & 2.74 & - & - & - \\
\hline 22 April 2007 & II & 0.58 & - & 4.44 & 0.52 & 0.01 & 0.01 \\
\hline 28 April 2007 & $\mathrm{Ib}$ & 1.61 & 1.40 & 5.48 & 0.87 & 0.03 & 0.02 \\
\hline 29 April 2007 & II & 2.13 & 1.59 & - & 1.30 & 0.02 & 0.02 \\
\hline 30 April 2007 & $\mathrm{Ib}$ & 0.99 & 1.96 & 3.86 & 1.28 & 0.04 & 0.02 \\
\hline 1 May 2007 & $\mathrm{Ib}$ & 1.34 & 1.08 & - & 0.73 & 0.02 & 0.02 \\
\hline 2 May 2007 & II & - & - & - & - & - & - \\
\hline 5 May 2007 & Ia & 1.77 & 5.14 & 2.28 & 5.24 & 0.03 & 0.03 \\
\hline 6 May 2007 & II & - & - & - & - & - & - \\
\hline 7 May 2007 & $\mathrm{Ib}$ & 1.84 & 2.03 & 4.42 & 0.94 & 0.04 & 0.03 \\
\hline 11 May 2007 & $\mathrm{Ib}$ & 3.87 & 1.14 & 2.34 & 1.68 & 0.03 & 0.05 \\
\hline 13 Маy 2007 & $\mathrm{Ib}$ & 4.25 & 1.54 & 4.20 & 0.97 & 0.07 & 0.09 \\
\hline 14 May 2007 & II & - & 12.84 & 11.93 & - & - & - \\
\hline 15 May 2007 & II & 0.81 & 3.67 & - & - & - & - \\
\hline 16 May 2007 & II & 1.97 & 0.99 & - & 2.22 & 0.03 & 0.01 \\
\hline 17 May 2007 & $\mathrm{Ib}$ & 2.48 & 1.73 & 3.81 & 1.06 & 0.04 & 0.05 \\
\hline 18 May 2007 & Ia & 1.89 & 4.54 & 3.37 & 1.29 & 0.04 & 0.05 \\
\hline 21 May 2007 & II & - & 4.11 & - & - & - & - \\
\hline 22 May 2007 & $\mathrm{Ib}$ & - & 16.67 & 11.33 & - & - & - \\
\hline 31 May 2007 & II & - & - & 13.46 & - & - & - \\
\hline 1 June 2007 & $\mathrm{Ib}$ & 1.72 & 3.42 & 5.44 & 0.89 & 0.02 & 0.03 \\
\hline 2 June 2007 & II & - & - & - & - & - & - \\
\hline 3 June 2007 & II & 0.94 & - & 14.79 & 0.46 & 0.02 & 0.04 \\
\hline 8 June 2007 & II & - & 3.96 & 6.10 & - & - & - \\
\hline 16 June 2007 & II & - & - & - & - & - & - \\
\hline 22 June 2007 & II & 3.21 & - & 17.61 & 0.48 & 0.04 & 0.06 \\
\hline 25 June 2007 & $\mathrm{Ib}$ & 1.69 & 3.13 & 23.05 & 0.44 & 0.02 & 0.03 \\
\hline
\end{tabular}

contribution of neutral particles to the NPF event was higher than the contribution of charged particles. In this study the dominance of the neutral over the ion-induced nucleation was clear. The ions and their recombination explained approximately $10 \%$ of the total particle formation. The median ion-ion recombination rate was $0.05 \mathrm{~cm}^{-3} \mathrm{~s}^{-1}$. As a summary, the results indicate that ion-induced nucleation involv- ing ion-ion recombination products have a minor role in boreal forest new particle formation events. Nevertheless, the ion-induced nucleation may have more important role in the particle formation events under substantially different atmospheric conditions or in other locations or altitudes of the atmosphere (Kazil et al., 2008). 
Acknowledgements. We thank organizers of the intensive EUCAARI 2007 field campaign in Hyytiälä and all the researchers, technical staff and students who took part in performing the field measurements used in this study. This work has been partially funded by European Commission 6th Framework program project EUCAARI, contract no 036833-2 (EUCAARI). The support by the Academy of Finland is also gratefully acknowledged.

Edited by: A. Wiedensohler

\section{References}

Aalto, P., Hämeri, K., Becker, E., Weber, R., Salm, J., Mäkelä, J. M., Hoell, C., O’Dowd, C. D., Karlsson, H., Hansson, H.-C., Väkevä, M., Koponen, I. K., Buzorius, G., and Kulmala, M.: Physical characterization of aerosol particles during nucleation events, Tellus 53B, 344-358, 2001.

Asmi, E., Sipilä, M., Manninen, H. E., Vanhanen, J., Lehtipalo, K., Gagné, S., Neitola, K., Mirme, A., Mirme, S., Tamm, E., Uin, J., Komsaare, K., Attoui, M., and Kulmala, M.: Results of the first air ion spectrometer calibration and intercomparison workshop, Atmos. Chem. Phys., 9, 141-154, 2009, http://www.atmos-chem-phys.net/9/141/2009/.

Cabada, J. C., Khlystov, A., Wittig, A. E., Pilinis, C., and Pandis, S. N.: Light scattering by fine particles during the Pittsburgh Air Quality Study: Measurements and modeling, J. Geophys. Res., 109, D16S03, doi:10.1029/2003JD004155, 2004.

Dal Maso, M., Kulmala, M., Riipinen, I., Wagner, R., Hussein, T., Aalto, P. P., and Lehtinen, K. E. J.: Formation and growth of fresh atmospheric aerosols: eight years of aerosol size distribution data from SMEAR II, Hyytiälä, Finland, Boreal Environ. Res., 10, 323-336, 2005.

Ehn, M., Petäjä, T., Aufmhoff, H., Aalto, P., Hämeri, K., Arnold, F., Laaksonen, A., and Kulmala, M.: Hygroscopic properties of ultrafine aerosol particles in the boreal forest: diurnal variation, solubility and the influence of sulfuric acid, Atmos. Chem. Phys., 7, 211-222, 2007,

http://www.atmos-chem-phys.net/7/211/2007/.

Eisele, F. L., Lovejoy, E. R., Kosciuch, E., Moore, K. F., Mauldin III, R. L., Smith, J. N., McMurry, P. H., and Iida, K.: Negative atmospheric ions and their potential role in ion-induced nucleation, J. Geophys. Res., 111, D04305, doi:10.1029/2005JD006568, 2006.

Gagné, S., Laakso, L., Petäjä, T., Kerminen, V.-M., and Kulmala, M.: Analysis of one year of Ion-DMPS data from the SMEAR II station, Finland, Tellus, 60B, 318-329, 2008.

Hari, P. and Kulmala, M.: Station for measuring ecosystematmosphere relations (SMEAR II), Boreal Environ. Res., 10, 315-322, 2005.

Hirsikko, A., Laakso, L., Hörrak, U., Aalto, P. P., Kerminen, V.M., and Kulmala, M.: Annual and size dependent variation of growth rates and ion concentrations in boreal forest, Boreal Environ. Res., 10, 357-369, 2005.

Hirsikko, A., Bergman, T., Laakso, L., Dal Maso, M., Riipinen, I., Hõrrak, U., and Kulmala, M.: Identification and classification of the formation of intermediate ions measured in boreal forest, Atmos. Chem. Phys., 7, 201-210, 2007, http://www.atmos-chem-phys.net/7/201/2007/.
Iida, K., Stolzenburg, M., McMurry, P., Dunn, M. J., Smith, J. N., Eisele, F., and Keady, P.: Contribution of ion-induced nucleation to new particle formation: Methodology and its application to atmospheric observations in Boulder, Colorado, J. Geophys. Res., 111, D23201, doi:10.1029/2006JD007167, 2006.

IPCC: Intergovernmental Panel on Climate Change. Climate Change 2007 - The Physical Science Basis: Contribution of Working Group I to the Fourth Assessment Report of the IPCC, Cambridge: Cambridge University Press, 2007.

Jokinen, V. and Mäkelä, J.: Closed loop arrangement with critical orifice for DMA sheath/excess flow system, J. Aerosol Sci., 28, 643-648, 1996.

Kazil, J., Harrison, R. G., and Lovejoy, E. R.: Tropospheric new particle formation and the role of ions, Space Sci. Rev. 137, 241255, 2008.

Kerminen, V.-M., Lehtinen, K. E. J., Anttila, T., and Kulmala, M.: Dynamics of atmospheric nucleation mode particles: a timescale analysis, Tellus, 56B, 135-146, 2004.

Kerminen, V.-M., Lihavainen, H., Komppula, M., Viisanen, Y., and Kulmala, M.: Direct observational evidence linking atmospheric aerosol formation and cloud droplet activation, Geophys. Res. Lett., 32, L14803, doi:10.1029/2005GL023130, 2005.

Kulmala, M., Dal Maso, M., Mäkelä, J. M., Pirjola, L., Väkevä, M., Aalto, P, Miikkulainen, P., Hämeri, K., and O'Dowd, C. D.: On the formation, growth and composition of nucleation mode particles, Tellus, 53B, 479-490, 2001.

Kulmala, M., Vehkamäki, H., Petäjä, T., Dal Maso, M., Lauri, A., Kerminen, V.-M., Birmili, W., and McMurry, P. H.: Formation and growth rates of ultrafine atmospheric particles: A review of observations, J. Aerosol Sci., 35, 143-176, 2004a.

Kulmala, M., Laakso, L., Lehtinen, K. E. J., Riipinen, I., Dal Maso, M., Anttila, T., Kerminen, V.-M., Hörrak, U., Vana, M., and Tammet, H.: Initial steps of aerosol growth, Atmos. Chem. Phys., 4, 2553-2560, 2004b, http://www.atmos-chem-phys.net/4/2553/2004/.

Kulmala, M., Riipinen, I., Sipilä, M., Manninen, H. E., Petäjä, T., Junninen, H., Dal Mso, M., Mordas, G., Mirme, A., Vana., M., Hirsikko, A., Laakso, L., Harrison, R. M., Hanson, I., Leung, C., Lehtinen, K. E. J., and Kerminen, V.-M.: Towards direct measurements of atmospheric nucleation, Science, 318, 89-92, 2007a.

Kulmala, M., Mordas, G., Petäjä, T., Grönholm, T., Aalto, P. P., Vehkamäki, H., Hienola, A. I., Herrmann, E., Sipilä, M., Riipinen, I., Manninen, H. E., Hämeri, K., Stratman, F., Bilde, M., Winkler, P. M., Wolfram, B., and Wagner, P. E.: The Condensation Particle Counter Battery (CPCB): A new tool to investigate the activation properties of nanoparticles, J. Aerosol Sci., 38, 289-304, 2007b.

Kulmala, M. and Kerminen, V.-M.: On the growth of atmospheric nanoparticles, Atmos. Res., 90, 132-150, 2008.

Kulmala, M., Asmi, A., Lappalainen, H. K., Carslaw, K. S., Pöschl, U., Baltensperger, U., Hov, Ø., Brenquier, J.-L., Pandis, S. N., Facchini, M. C., Hansson, H.-C., Wiedensohler, A., and O'Dowd, C. D.: Introduction: European Integrated project on Aerosol Cloud Climate and Air Quality interactions (EUCAARI) - integrating aerosol research from nano to global scales, Atmos. Chem. Phys., 9, 2825-2841, 2009, http://www.atmos-chem-phys.net/9/2825/2009/. 
Kuwata, M., Kondo, Y., Miyazaki, Y., Komazaki, Y., Kim, J. H., Yum, S. S., Tanimoto, H., and Matsueda, H.: Cloud condensation nuclei activity at Jeju Island, Korea in spring 2005, Atmos. Chem. Phys., 8, 2933-2948, 2008,

http://www.atmos-chem-phys.net/8/2933/2008/.

Laakso, L., Anttila, T., Lehtinen, K. E. J., Aalto, P. P., Kulmala, M., Hõrrak, U., Paatero, J., Hanke, M., and Arnold, F.: Kinetic nucleation and ions in boreal particle formation events, Atmos. Chem. Phys., 4, 2353-2366, 2004,

http://www.atmos-chem-phys.net/4/2353/2004/.

Laakso, L., Laakso, H., Aalto, P. P., Keronen, P., Petäjä, T., Nieminen, T., Pohja, T., Siivola, E., Kulmala, M., Kgabi, N., Molefe, M., Mabaso, D., Phalatse, D., Pienaar, K., and Kerminen, V.-M.: Basic characteristics of atmospheric particles, trace gases and meteorology in a relatively clean Southern African Savannah environment, Atmos. Chem. Phys., 8, 4823-4839, 2008, http://www.atmos-chem-phys.net/8/4823/2008/.

Lihavainen, H., Kerminen, V.-M., Komppula, M., Hatakka, J., Aaltonen, V., Kulmala, M., Viisanen, Y.: Production of "potential" cloud condensation nuclei associated with atmospheric new-particle formation in northern Finland, J. Geophys. Res., 108(D24), 4782, doi:10.1029/2003JD003887, 2003.

Lohmann, U. and Feichter, J.: Global indirect aerosol effects: A review, Atmos. Chem. Phys., 5, 715-737, 2005,

http://www.atmos-chem-phys.net/5/715/2005/.

McMurry, P. H.: The History of CPCs, Aerosol Sci. Technol., 33, 297-322, 2000.

McMurry, P. H., Fink, M., Sakurai, H., Stolzenburg, M. R., Mauldin, R. L., III, Smith, J., Eisele, F., Moore, K., Sjostedt, S., Tanner, D., Huey, L. G., Nowak, J. B., Edgerton, E., and Voisin, D.: A criterion for new particle formation in the sulfurrich Atlanta atmosphere, J. Geophys. Res., 110, D22, D22S02, doi:10.1029/2005JD005901, 2005.

Mirme, A., Tamm, A., Mordas, G., Vana, M., Uin, J., Mirme, S., Bernotas, T., Laakso, L., Hirsikko, A., and Kulmala, M.: A Wide-range multi-channel Air Ion Spectrometer, Boreal Environ. Res., 12, 247-264, 2007.

Mäkelä, J. M., Riihelä, M., Ukkonen, A., Jokinen, V., and Keskinen, J.: Comparison of mobility equivalent diameter with KelvinThomson diameter using ion mobility data, J. Chem. Phys., 105, 1562-1571, 1996.

Mäkelä, J. M., Dal Maso, M., Pirjola, L., Keronen, P., Laakso, L., Kulmala, M., and Laaksonen, A.: Characteristics of the atmospheric particle formation events observed at a boreal forest site in southern Finland, Boreal Environ. Res., 5, 299-313, 2000.

O'Dowd, C., Aalto, P., Hämeri, K., Kulmala, M., and Hoffman, T.: Atmospheric particles from organic vapours, Nature, 416-498, 2002.

Petäjä, T., Mordas, G., Manninen, H., Aalto, P. P., Hämeri, K., and Kulmala, M.: Detection efficiency of a water-based TSI Condensation Particle Counter 3785, Aerosol Sci. Technol., 40, 10901097, 2006.

Riipinen, I., Manninen, H. E., Yli-Juuti, T., Boy, M., Sipilä, M., Ehn, M., Junninen, H., Petäjä, T., and Kulmala, M.: Applying the Condensation Particle Counter Battery (CPCB) to study the water-affinity of freshly-formed 2-9 nm particles in boreal forest, Atmos. Chem. Phys., 9, 3317-3330, 2009,

http://www.atmos-chem-phys.net/9/3317/2009/.
Sipilä, M., Lehtipalo, K., Kulmala, M., Petäjä, T., Junninen, H., Aalto, P. P., Manninen, H. E., Kyrö, E.-M., Asmi, E., Riipinen, I., Curtius, J., Kürten, A., Borrmann, S., and O'Dowd, C. D.: Applicability of condensation particle counters to measure atmospheric clusters, Atmos. Chem. Phys., 8, 4049-4060, 2008 , http://www.atmos-chem-phys.net/8/4049/2008/.

Sipilä, M., Lehtipalo, K., Attoui, M., Neitola, K., Petäjä, T., Aalto, P. P., O'Dowd, C., and Kulmala, M.: Laboratory Verification of PH-CPC's Ability to Monitor Atmospheric Sub-3 nm Clusters, Aerosol Sci. Technol., 43, 2, (February 2009), 126-135, 2009.

Smith, J. N., Dunn, M. J., VanReken, T. M., Iida, K., Stolzenburg, M. R., McMurry, P. H., and Huey, L. G.: Chemical composition of atmospheric nanoparticles formed from nucleation in Tecamac, Mexico: Evidence for an important role for organic species in nanoparticle growth, Geophys. Res. Lett., 35, L04808, doi:10.1029/2007GL032523, 2008.

Spracklen, D. V., Carslaw, K. S., Kulmala, M., Kerminen, V.-M., Mann, G. W., and Sihto, S.-L.: The contribution of boundary layer nucleation events to total particle concentrations on regional and global scales, Atmos. Chem. Phys., 6, 5631-5648, 2006, http://www.atmos-chem-phys.net/6/5631/2006/.

Spracklen, D. V., Carslaw, K. S., Kulmala, M., Kerminen, V.-M., Sihto, S.-L., Riipinen, I., Merikanto, J., Mann, G. W., Chipperfield, M. P., Wiedensohler, A., Birmili, W., and Lihavainen, H.: Contribution of particle formation to global cloud condensation nuclei concentrations, Geophys. Res. Lett., 35, L06808, doi:10.1029/2007GL033038, 2008.

Stolzenburg, M. R., McMurry, P. H., Sakurai, H., Smith, J. N., Mauldin III, R. L., Eisele, F. L., and Clement, C. F.: Growth rates of freshly nucleated atmospheric particles in Atlanta, J. Geophys. Res., 110, D22S05, doi:10.1029/2005JD005935, 2005.

Tammet, H.: Size and mobility of nanoparticles, clusters and ions, J. Aerosol Sci., 26, 459-475, 1995.

Tammet, H. and Kulmala, M.: Simulation tool for atmospheric aerosol nucleation bursts, J. Aerosol Sci., 36, 173-196, 2005.

Tammet, H.: Continuous scanning of the mobility and size distribution of charged clusters and nanometer particles in atmospheric air and the Balanced Scanning Mobility Analyzer BSMA, Atmos. Res., 82, 523-535, 2006.

Tarvainen, V., Hakola, H., Hellén, H., Bäck, J., Hari, P., and Kulmala, M.: Temperature and light dependence of the VOC emissions of Scots pine, Atmos. Chem. Phys., 5, 989-998, 2005, http://www.atmos-chem-phys.net/5/989/2005/.

Venzac, H., Sellegri, K., Laj, P., Villani, P., Bonasoni, P., Marinoni, A., Cristofanelli, P., Calzolari, F., Fuzzi, S., Decesari, S., Facchini, M.-C., Vuillermoz, E., and Verza, G. P.: High frequency new particle formation in the Himalayas, Proc. Natl. Acad. Sci. USA, 105, 15666-15671, 2008.

Yu, F. and Turco, R.: Case studies of particle formation events observed in boreal forests: implications for nucleation mechanisms, Atmos. Chem. Phys., 8, 6085-6102, 2008, http://www.atmos-chem-phys.net/8/6085/2008/.

Yu, F., Wang, Z., Luo, G., and Turco, R.: Ion-mediated nucleation as an important global source of tropospheric aerosols, Atmos. Chem. Phys., 8, 2537-2554, 2008, http://www.atmos-chem-phys.net/8/2537/2008/. 
Winkler, P. M., Steiner, G., Virtala, A., Vehkamäki, H., Noppel, M., Lehtinen, K. E. J., Reischl, G. P., Wagner, P. E., and Kulmala, M.: Heterogeneous Nucleation Experiments Bridging the Scale from Molecular Ion Clusters to Nanoparticles, Science, 319, 1374, doi:10.1126/science.1149034, 2008.
Wu, Z., Hu, M., Liu, S., Wehner, B., Bauer, S., Maßling, A., Wiedensohler, A., Petäjä, T., Dal Maso, M., and Kulmala, M.: New particle formation in Beijing, China: Statistical analysis of a 1-year data set, J. Geophys. Res., 112, D09209, doi:10.1029/2006JD007406, 2007. 